Article

\title{
F-Gases: Trends, Applications and Newly Applied Gases in the Czech Republic
}

\author{
Markéta Müllerová ${ }^{1}$, Eva Krtková ${ }^{1, *}$ and Zuzana Rošková ${ }^{1,2}$ \\ 1 National Inventory System for GHG Emissions, Air Quality Protection Division, \\ Czech Hydrometeorological Institute, Na Šabatce 2050/17, 14306 Praha, Czech Republic; \\ marketa.mullerova@chmi.cz (M.M.); zuzana.roskova@chmi.cz (Z.R.) \\ 2 Department of Environmental Chemistry, Faculty of Environmental Technology, University of Chemistry \& \\ Technology in Prague, Technická 5, 16628 Praha, Czech Republic \\ * Correspondence: eva.krtkova@chmi.cz; Tel.: +420-244-032-422
}

Received: 24 March 2020; Accepted: 24 April 2020; Published: 30 April 2020

check for updates

\begin{abstract}
Emissions of fluorinated greenhouse gases (F-gases), which are used as replacements for ozone-depleting substances, have risen sharply since 1995. The rapid increase in F-gas emissions coupled with their global warming potential (GWP) has led to increased worldwide attention to monitoring emission levels and subsequently regulating the use of F-gases. These restrictions apply in particular to applications for which alternative technologies are available that are more economically efficient and have minor or no impact on the Earth's climate system. This paper brings new information about changes in composition of consumed F-gases in the Czech Republic. Since no F-gases are produced in the country, data about F-gas consumption are obtained from three resources which give information about import and export. The paper also describes implementation of newly used F-gases, which are used as replacements for specific F-gases, into emission calculation models. Emissions are estimated according to the methodology developed by the Intergovernmental Panel on Climate Change (IPCC). Although consumption of F-gases with high GWP has already started decreasing, it will have no effect on F-gas emissions for several years.
\end{abstract}

Keywords: F-gases; greenhouse gases; global warming potential; substitutes for ozone depleting substances; Czech Republic

\section{Introduction}

Fluorinated greenhouse gases (F-gases) are anthropogenic gases used mainly as substitutes for ozone-depleting substances. Although F-gases do not damage the atmospheric ozone layer, they contribute significantly to the global greenhouse effect [1]. Two main groups of F-gases can be distinguished; hydrofluorocarbons (HFCs) and perfluorocarbons (PFCs) [2]. The difference between the HFCs and PFCs groups is in the degree of fluorination. The first group consists in partly fluorinated F-gases, whereas the second group contains fully fluorinated molecules [3]. There is an important difference between these two groups, especially in terms of the greenhouse effect, i.e., their lifetimes in the atmosphere. While the lifetime of HFCs varies between a few days and 250 years, most PFCs can remain in the atmosphere for thousands of years [4]. F-gases are used, for instance, as fire suppressors, aerosols, refrigerants in refrigerators, in air conditioning systems, etc.

Since global warming potential (GWP) of F-gases is many times greater than that of carbon dioxide $\left(\mathrm{CO}_{2}\right)$, the EU is taking regulatory action to control them [4]. GWP measures how much energy 1 ton of a gas will absorb over a certain time period, relative to 1 ton of $\mathrm{CO}_{2}$ [5]. Regulation (EU) 517/2014 outlines guidelines and information about reporting by companies. Directive 2006/40/EC (and also the MAC (mobile air conditioning) Directive) is focused on prohibition of using F-gases in mobile 
air conditioning. But it does not suggest any way to accomplish this goal [6]. F-gases are subject to a reporting duty. Facilities that produce, import or export 1 metric ton or 100 tones $\mathrm{CO}_{2}$ eq. and more F-gases must report such information [7].

In the following chapters, European legislative measures are described in more detail, it is shown how they affect composition of consumed F-gases in the Czech Republic, and information about newly used F-gases is added in the same way as information about their integration into the F-gas emission calculation model PHOENIX, which is a country specific estimation model for F-gas emissions. Newly applied F-gases change the results of the F-gas emissions in the Czech Republic and affect in this way also the total emission from greenhouse gases. The PHOENIX model is continuously improved to provide accurate and transparent results.

The paper provides an overview of the trends of F-gases used in the Czech Republic including recent updates and changes following application of the newly developed F-gases with low GWP.

\section{Regulation (European Union, EU) No 517/2014 and Mobile Air Conditioning (MAC) Directive}

This regulation was published after approval by the European Parliament (EP) and the Council in April 2014. The Regulation is based on Regulation (EC) No 842/2006 on certain fluorinated greenhouse gases. The aim of the Regulation is to reduce emissions of F-gases, which have to be decreased by $72-73 \%$ by 2030 against the reference year of 1990 . The regulation therefore provides rules on containment, use, recovery and destruction of F-gases and conditions on the placing on the market complemented by quantitative limits [8].

The objective of the regulation could be achieved, e.g., by replacing current gases with high GWP to gases with lower impact or, preferably, with no impact on the climate. In this context, the regulation also provides rules for training responsible persons for the safe-handling of alternative refrigerants, because some alternatives to F-gases have undesirable properties, such as lower flash point and toxicity [8].

The measures which entered into force on 1 January 2020 affect a wide range of equipment. From this date, it is prohibited to place on the market:

- Mobile room air-conditioning equipment that contains HFCs with GWP of 150 or more;

- Refrigerators and freezers for commercial use that contain HFCs with GWP of 2500 or more (starting 2022, limit of GWP will be 150);

- Stationary refrigeration equipment that contains HFCs with GWP of 2500 or more.

These measures have an impact on the use of the mixtures R-404a (GWP 3943 [4]) and R-507a (GWP 3985 [4]), which are mainly used in stationary commercial refrigeration [9].

The subject of the MAC Directive is to lay down the requirements for air-conditioning systems fitted into vehicles. The directive applies to passenger cars comprising no more than eight seats in addition to the driver's seat and vehicles designed and constructed for the carriage of goods and having a maximum mass not exceeding 1305 kilograms. Since 1 January 2017, mobile air-conditioning systems in new vehicles, which are brought into service in the EU, must not contain gases with GWP of 150 and more [6].

\section{Trends and Applications in the Czech Republic}

The base year for reporting obligation of F-gases in the Czech Republic is 1995. F-gases are not produced in this country and all of them are imported. Data about direct import/export, use and destruction are obtained from ISPOP (Integrated system of reporting obligations), the F-gas register (Questionnaire on production, import, export, feedstock use and destruction of the substances listed in Annexes I or II of the F-gas regulation) and the Customs Administration of the Czech Republic [10].

The major share of F-gases (about 99\%) is used for refrigeration and air conditioning systems, approximately $75 \%$ of F-gases is used for refrigeration and stationary air conditioning and $25 \%$ is used 
in mobile air conditioning. Manufacturers use a wide range of mixtures containing HFCs. In the past, mixtures containing PFCs were also used, but these mixtures has not been used since 2010 [10].

\subsection{Refrigeration and Stationary Air-Conditioning Systems}

ISPOP provides information about import, export, regeneration, destruction and the first placing on the market of F-gases. The ISPOP database contains the EU market data. The threshold for submitting data to ISPOP by importers, exporters and users is 0.1 metric tonne of F-gases. The F-gas register provides data about the imported, exported and disposed amounts of F-gases and also contains information about the average specific charge of equipment, amount of imported, exported or disposed equipment and information about specific use of the equipment. Information in the F-gas register is related to the trade between EU countries and non-EU countries and the threshold for submitting data to the F-gas register is more than 1 metric tonne of F-gases. The threshold refers to the sum of F-gases, not each imported/exported gas separately. Customs data provide information about trading between the Czech Republic and the global market. These data provide information about imported/exported products and containers of fluorinated greenhouse gases; information is classified according to the combined nomenclature, which is regularly updated [10].

The global market is covered in the inventory since the data sources cover trade between the Czech Republic and EU countries and also non-EU countries. Verification of the data by each importer/exporter/user of F-gases in all the data sources is a very important step in the process of inventory preparation, because it is necessary to avoid double counting [10].

The main type of mixture used in the Czech Republic for stationary air conditioning/refrigeration is R-410a [9] (GWP 1924 [4]), a mixture of HFC-32 and HFC-125 in a ratio of 50:50. Mixtures R-407c, R-507a and R-404a are used in smaller amounts. R-407c (GWP 1624 [4]) is a mixture of HFC-32, HFC-125 and HFC-134a in a ratio of 23:25:52 and it is used mainly in stationary air conditioning. R-507a is a mixture of HFC-125 and HFC-143a in a ratio of 50:50. R-404a contains HFC-125, HFC-143a and HFC-134a gases in a ratio of 44:52:4 [10].

In the national inventory, mixtures are compartmentalized into individual gases. The trend of use of particular F-gases is depicted in Figure 1. As can be seen, there was a significant decrease in the use of HFC-125, and HFC-143a even did not appear in the market in 2018. These two gases have high GWP, and their decrease is based on the fact that manufacturers are preparing for limitation of these gases and their mixtures. As can be seen on the second graph in Figure 1a,b, although the amount of F-gases used in 2018 is similar to in 2017, the used gases have a smaller impact on global warming.


Figure 1. Trend in F-gases used for refrigerants and air conditioning in the Czech Republic in tonnes

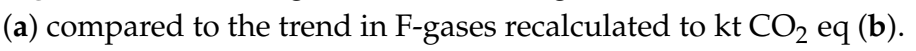


The EU regulations force manufacturers to find alternatives to F-gases with high GWP. One option for them is to develop new mixtures with lower GWP. Another option is to use natural refrigerants, such as ammonia, isobutene, propane and $\mathrm{CO}_{2}$, which have already been used in the past [11]. The coming years will show which option is more convenient for manufacturers; nevertheless, we can expect a gradual decrease in the use of F-gases in this field.

\subsection{Mobile Air Conditioning}

A different approach than for refrigeration and stationary air conditioning is used for estimation of the amount of F-gases employed in mobile air conditioning. The data collection is based on knowledge of the number of vehicles, percentage of vehicles with air conditioning and average amount of refrigerants in these vehicles. Data about production are obtained from the Automotive Industry Association. These data contain the production figures for the Czech automobile industry since 1995. Three car producers (ŠKODA AUTO Inc., Hyundai Motor Manufacturing Czech Ltd. and TPCA), bus producers (SOR Libchavy Ltd., Iveco Czech Republic Inc. and others) and one truck producer (TATRA TRUCKS Inc.) are currently operating in the Czech Republic. More detailed data about production (e.g., production of particular models) are obtained directly from ŠKODA AUTO Inc. and TPCA, whose production covers approximately $85 \%$ of all new passenger cars produced in the Czech Republic. Knowledge of the production of particular models makes determination of the average initial charge more accurate. The initial charge of passenger cars decreased over the years from $750 \mathrm{~g}$ per unit to $500 \mathrm{~g}$ per unit [10].

The only refrigerant used for mobile air conditioning from 1995 to 2015 was HFC-134a (GWP 1300 [4]). Since 2015, it has been prohibited to use this gas in mobile air conditioning and manufacturers have started filling cars for the EU market with hydrofluoroolefin (HFO)-1234yf and this gas has been the main refrigerator in mobile air conditioning since then. This change is the result of implementation of the MAC Directive. It is assumed that HFO-1234yf will not be replaced by some other refrigerant in next few years, so its consumption will depend solely on the number of cars produced. As can be seen from the second graph in Figure 2a,b, the impact of HFO-1234yf on global warming is more than thousand times smaller than the impact of HFC-134a. More detailed comparison of these two gases is presented in the following section.
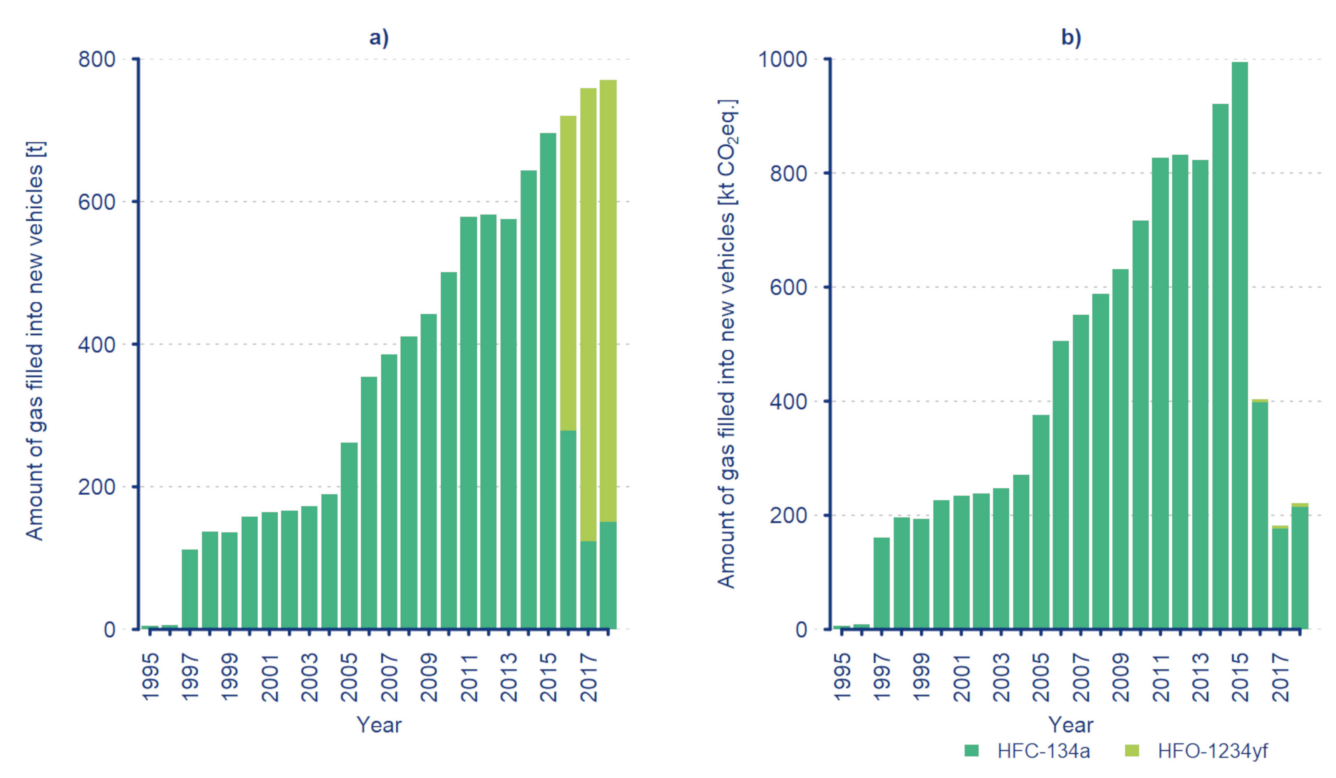

Figure 2. The trend in gases filled into new vehicles in the Czech Republic in tonnes (a) compared to

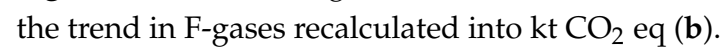




\section{Newly Employed F-Gases in the Czech Republic}

HFO-1234yf and HFO-1234ze are newly used as alternatives to HFC-134a. Both new HFCs have an olefinic structure and low GWP. Because of their structure they are called hydrofluoroolefins (HFOs) [12].

There are apparent some similarities between HFO-1234ze(E), HFO-1234yf and the older F-gas HFC-134a summarized in Table 1. Their chemical structures are also similar. A slight difference is caused by the position of the F atom in the olefinic part of the molecule (which is shown in Figure 3). Because of their harmful potential, the American Industrial Hygiene Association (AIHA) set workplace environmental exposure levels (WEEL), for HFO-1234ze equal to $800 \mathrm{ml} . \mathrm{m}-3$ and, for HFO-1234yf, $500 \mathrm{ml} . \mathrm{m}-3$ per 8 hours shift [13]. Other thermodynamic properties of mentioned F-gases are captured in the Table 1 [14-17].

Table 1. Thermodynamic properties of hydrofluoroolefins (HFOs) compared to hydrofluorocarbon HFC-134a.

\begin{tabular}{cccccc}
\hline Properties & Units & HFO-1234ze(E) & HFO-1234ze(Z) & HFO-1234yf & HFC-134a \\
\hline CAS $^{1}$ & & $29118-24-9$ & $29118-25-0$ & $754-12-1$ & $811-97-2$ \\
Boiling point & ${ }^{\circ} \mathrm{C}$ & -19 & 10 & -29 & -26 \\
Critical point & ${ }^{\circ} \mathrm{C}$ & 109 & 150 & 95 & 102 \\
Vapour pressure & $\mathrm{kPa}$ & 500 & 184 & 677 & 665 \\
$\quad\left(25^{\circ} \mathrm{C}\right)$ & & {$[14]$} & {$[15,16]$} & & {$[17]$} \\
Source & & $<1$ & & $<1$ & 1300 \\
GWP [4] & & & & & \\
\hline
\end{tabular}

${ }^{1}$ CAS number is a registry number characteristic for each chemical. It was classified by Chemical Abstract Service (CAS). The number is divided into three parts. First part is the most variable, it could contain from 2 to 7 digits, second part contains only two and last just one digit. Those three parts are separated by a dash. Every chemical has its own CAS number which is specific for one substance.

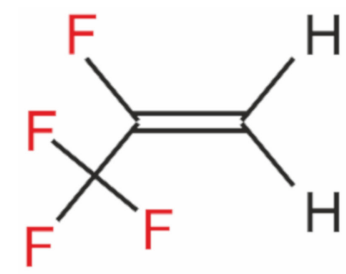

HFO-1234yf

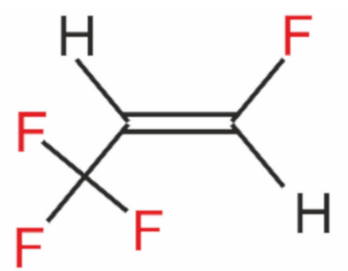

HFO-1234ze(E)

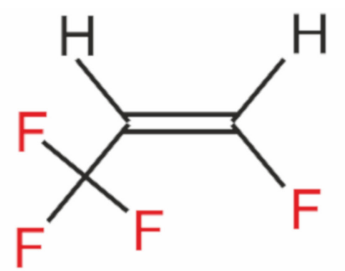

HFO-1234ze(Z)

Figure 3. This figure shows the chemical structures of HFO-1234yf and two isomers of HFO-1234ze [15].

\subsection{Hydrofluoroolefin (HFO)-1234yf}

A newly employed F-gas has the official designation HFO-1234yf (also R-1234yf or HFC-1234yf). The systematic chemical name for HFO-1234yf is 2, 3, 3, 3-tetrafluoroprop-1-ene.

HFO-1234yf belongs to third-generation refrigerants. Its GWP value is smaller than 1 [4] which is very low compared, e.g., with HFC-134a, whose GWP is 1300 [4]. Both these F-gases have quite similar vapour pressures under laboratory conditions and also similar boiling points and critical points. HFO-1234yf is poorly combustible but is slightly flammable. The flammability of the gas is a reason for concern. This behaviour of HFO-1234yf is the reason why greater specialisation is required for employees working with it, like safety training and how to handle flammable things, etc. [18]. HFO-1234yf shows slight activity in the Ames test, which is used for the testing mutagenic and carcinogenic activity of the tested substances. Further investigations did not find any mutagenic activity. Thus, HFO-1234yf does not cause any genetic changes and the doses are low for all the tests performed in the study by [19]. 


\subsection{HFO-1234ze}

HFO-1234ze has two isomeric structures: trans-1, 3, 3, 3-tetrafluoroprop-1-ene with suffix (E) or cis-1, 3, 3, 3-tetrafluoroprop-1-ene with suffix (Z) [20]. The suffixes are abbreviations of the German words Entgegen (E, opposite) and Zusammen (Z, together) [21]. HFO-1234ze(E) is used more often because of its similarity to its predecessor HFC-134a.

It has very low GWP and consequently it is used more often, as it has only small or no impact on the planet Earth. HFO-1234ze has been tested for its toxic and harmful potential for humans. The research of Rusch and his colleagues (2012) [22] was related to the inhalation toxicity of HFO-1234ze, showing that the effective dose is very high, i.e., HFO-1234ze has very low toxic potential. Nonetheless, they found that its target organs are the liver and kidneys. Some histopathological changes were found in these organs.

\subsection{Mixtures}

At the present time, manufactures can choose between mixtures which were used less often in the past, or mixtures with new gases. R-407 represents mixtures which have long been available but were of little interest to manufactures until the present time. Its GWP is still rather large; however, this mixture has a broad range of applications. It is used in commercial, industrial and transport refrigeration. R-449a, which includes HFO-1234yf, is used in the same area. Mixture R-452a, also with HFO-1234yf, is used chiefly in transport refrigeration.

Mixtures that replace HFC-134a still contain this gas to which new kinds of gases are added. These include HFO-1234yf for R-513a and HFO-1234ze for R-450a. These mixtures are used in mediumand high-temperature commercial and industry refrigeration, air conditioning and heat pumps. Table 2 shows overview of mostly widely used replacement mixtures in the Czech Republic.

Table 2. Overview of mostly widely used replacement mixtures in the Czech Republic [23].

\begin{tabular}{ccccccc}
\hline \multirow{2}{*}{ Gas } & Substitute of: & \multicolumn{5}{c}{ Constituents } \\
\cline { 3 - 6 } & & HFC-134a & HFC-125 & HFC-32 & HFO-1234yf & HFO-1234ze \\
\hline R-407a & R-404a/R-507a & $40 \%$ & $40 \%$ & $20 \%$ & & 1923 \\
R-449a & R-404a/R-507a & $25.7 \%$ & $24.7 \%$ & $24.3 \%$ & $25.3 \%$ & 1282 \\
R-452a & R-404a/R-507a & & $59 \%$ & $11 \%$ & $30 \%$ & 575 \\
R-513a & HFC-134a & $44 \%$ & & & $56 \%$ & $58 \%$ \\
R-450a & HFC-134a & $42 \%$ & & & 547 \\
\hline
\end{tabular}

${ }^{1}$ Calculated according 5th Intergovernmental Panel on Climate Change (IPCC) Assessment Report, no climate feedbacks are included.

Other newly developed mixtures, which haven't been introduced on the market yet, commonly combine formerly used HFCs with new HFOs in various ratios.

\section{Calculation of Emissions from Refrigeration and Stationary Air Conditioning in the Czech Republic}

Emissions from refrigeration and stationary air-conditioning systems are estimated with the national PHOENIX calculation model defined according to the methodology developed by the Intergovernmental Panel on Climate Change (IPCC). In the inventory, five sub-applications are defined: commercial, domestic, industrial, and transport refrigeration and stationary air conditioning [24].

When calculating emissions of F-gases, time lag between consumption and emissions is taken in account. Time lag results from the fact that a chemical placed into a new product may only slowly leak out over time, not being released until end-of-life. Thanks to this and according to data availability, emissions can be estimated in a various ways with varying degrees of complexity and data intensity [24]. In the Czech Republic, Tier 2a, called the Emission-factor approach, is used. It takes in account the national and regional regulations governing the use of F-gases, defines the emission factors for refrigerant charge, during operation, at servicing and at equipment end of life [24]. 
The calculation model is divided into four main parts: input, divider, emission estimates and output. In input, there are emission factors, legislative measures and annual data about consumption of F-gases for the initial filling of new equipment and for servicing equipment in use. Collecting of the data from annual consumption is described in Section 3.1 and legislative measures are described in Section 2. Emission factors are defined for each sub-application and life-cycle stage of gas. Emission factors used for emission estimates are shown in Table 3. Their selection should be based on the national information provided by manufacturers, service providers, disposal companies and other organizations. However, obtaining such detailed information is very difficult under the current state of administration in the Czech Republic and thus the emission factors are based on the expert judgement in the default ranges proposed by IPCC 2006 Gl., Table 7.9 [24].

Table 3. Emission factors used for emission estimates in 2018.

\begin{tabular}{cccccc}
\hline $\begin{array}{c}\text { Source } \\
\text { Sub-Application }\end{array}$ & $\begin{array}{c}\text { Lifetimes } \\
{[\text { Years] }}\end{array}$ & $\begin{array}{c}\text { Emission Factors } \\
{[\% \text { of Initial Charge/Year] }}\end{array}$ & \multicolumn{2}{c}{ End-of-Life Emissions [\%] } \\
\cline { 2 - 6 } Factor in Equation & $\mathbf{( d )}$ & $\mathbf{( k )}$ & $\begin{array}{c}\mathbf{( x )} \\
\text { Operation } \\
\text { Emissions }\end{array}$ & $\begin{array}{c}\text { Recovery } \\
\text { Efficiency }\end{array}$ & $\begin{array}{c}\text { Initial Charge } \\
\text { Remaining }\end{array}$ \\
\hline $\begin{array}{c}\text { Commercial } \\
\text { Refrigeration }\end{array}$ & 10.50 & 3.00 & 13.00 & 55.00 & 70.00 \\
$\begin{array}{c}\text { Domestic Refrigeration } \\
\text { Industrial Refrigeration }\end{array}$ & 13.50 & 0.50 & 3.50 & 55.00 & 70.00 \\
Transport Refrigeration & 17.00 & 3.00 & 13.00 & 55.00 & 70.00 \\
Stationary Air & 8.50 & 0.50 & 20.00 & 55.00 & 30.00 \\
Conditioning & 13.50 & 0.50 & 6.50 & 55.00 & 70.00 \\
\hline
\end{tabular}

Each gas is divided into six groups according its area of application. The percentage share of each gas in the area of application, as can be seen in Table 4, is currently based on sectoral expert judgement, which is supported by the data obtained from the Association of Refrigeration and Air Conditioning. As we can see, F-gases are mostly used for commercial refrigeration and have not been used for domestic refrigeration since 2015. For 2018 emission estimates, two new gases were included into calculation model: HFO-1234yf and HFO-1234ze. Their distribution by application area is based on information about distribution of gases and mixtures which these two gases replace.

Table 4. Distribution of HFCs use by application area used for emission calculations in 2018.

\begin{tabular}{|c|c|c|c|c|c|}
\hline $\begin{array}{l}\text { Reported } \\
\text { F-Gases }\end{array}$ & $\begin{array}{l}\text { Commercial } \\
\text { Refrigeration }\end{array}$ & $\begin{array}{c}\text { Domestic } \\
\text { Refrigeration }\end{array}$ & $\begin{array}{c}\text { Industrial } \\
\text { Refrigeration }\end{array}$ & $\begin{array}{c}\text { Transport } \\
\text { Refrigeration }\end{array}$ & $\begin{array}{l}\text { Stationary Air } \\
\text { Conditioning }\end{array}$ \\
\hline HFC-125 & $40 \%$ & $x$ & $15 \%$ & $5 \%$ & $40 \%$ \\
\hline HFC-143a & $60 \%$ & $x$ & $15 \%$ & $5 \%$ & $20 \%$ \\
\hline HFC-23 & $100 \%$ & $x$ & $x$ & $x$ & $x$ \\
\hline HFC-134a & $60 \%$ & $x$ & $15 \%$ & $5 \%$ & $20 \%$ \\
\hline HFC-227ea & $100 \%$ & $x$ & $x$ & $x$ & $x$ \\
\hline HFC-32 & $40 \%$ & $x$ & $15 \%$ & $5 \%$ & $40 \%$ \\
\hline HFC-152a & $100 \%$ & $x$ & $\mathrm{x}$ & $x$ & $x$ \\
\hline HFO-1234yf & $30 \%$ & $x$ & $8 \%$ & $53 \%$ & $10 \%$ \\
\hline HFO-1234ze & $53 \%$ & $x$ & $5 \%$ & $15 \%$ & $27 \%$ \\
\hline
\end{tabular}

Using the symbol $\mathrm{x}$ indicates, that the gas is not applied in the area.

Emission estimates of individual gases are calculated separately for each area of application. Calculations of emission estimates are identical for all the F-gases and all sub-applications; however, the difference is in use of specific emission factors for each area of application. Total emissions for individual F-gas in individual area of application are calculated as the sum of emissions from filling new equipment $E_{\text {charge }}$ emissions during the equipment lifetime $E_{\text {lifetime }}$ and emissions at the system end of life $E_{\text {end of life. }}$. 
Emissions form filling $E_{\text {charge }}$ for year $t$ are calculated according to the equation:

$$
E_{\text {charge, } t}=M_{t} \frac{k}{100}
$$

where $M_{t}$ is the amount of chemical used for the first fill and $k$ is the emission factor for assembly losses charged into new equipment (see Table 3).

Emissions during the lifetime $E_{\text {lifetime, } t}$ are calculated according to the equation:

$$
E_{\text {charge, } t}=B_{t} \frac{x}{100}
$$

where $B_{t}$ is the amount of chemical banked in the system and $x$ represents the annual emission rate (see Table 3). $B_{t}$ is calculated as:

$$
B_{t}=S_{t}-E_{\text {charge, } t}-E_{\text {end of life, } t}+B_{t-1}-E_{\text {liefetime, } t-1}
$$

where $S_{t}$ is the amount of chemical charged into equipment (amount of gas consumed in year $t$ ).

Emissions at the end of life $E_{\text {end of life, } t}$ are calculated according to the equation:

$$
E_{\text {end of life, } t}=H_{t}\left(1-\frac{\eta_{\text {rec }, d}}{100}\right)
$$

where $\eta_{r e c, d}$ is recovery efficiency at disposal (see Table 3 ). $H_{t}$ is the amount of chemical remaining in the system at decommissioning and is calculated by using a Gaussian model with mean at the lifetime expectancy [25].

As can be seen in Figure 4, although the trend in F-gas consumption varies, emissions are consistently increasing, which is caused by the time lag mentioned above. In the coming years, we can expect no change in the increasing trend since the effect of reducing F-gas consumption will appear with delay.

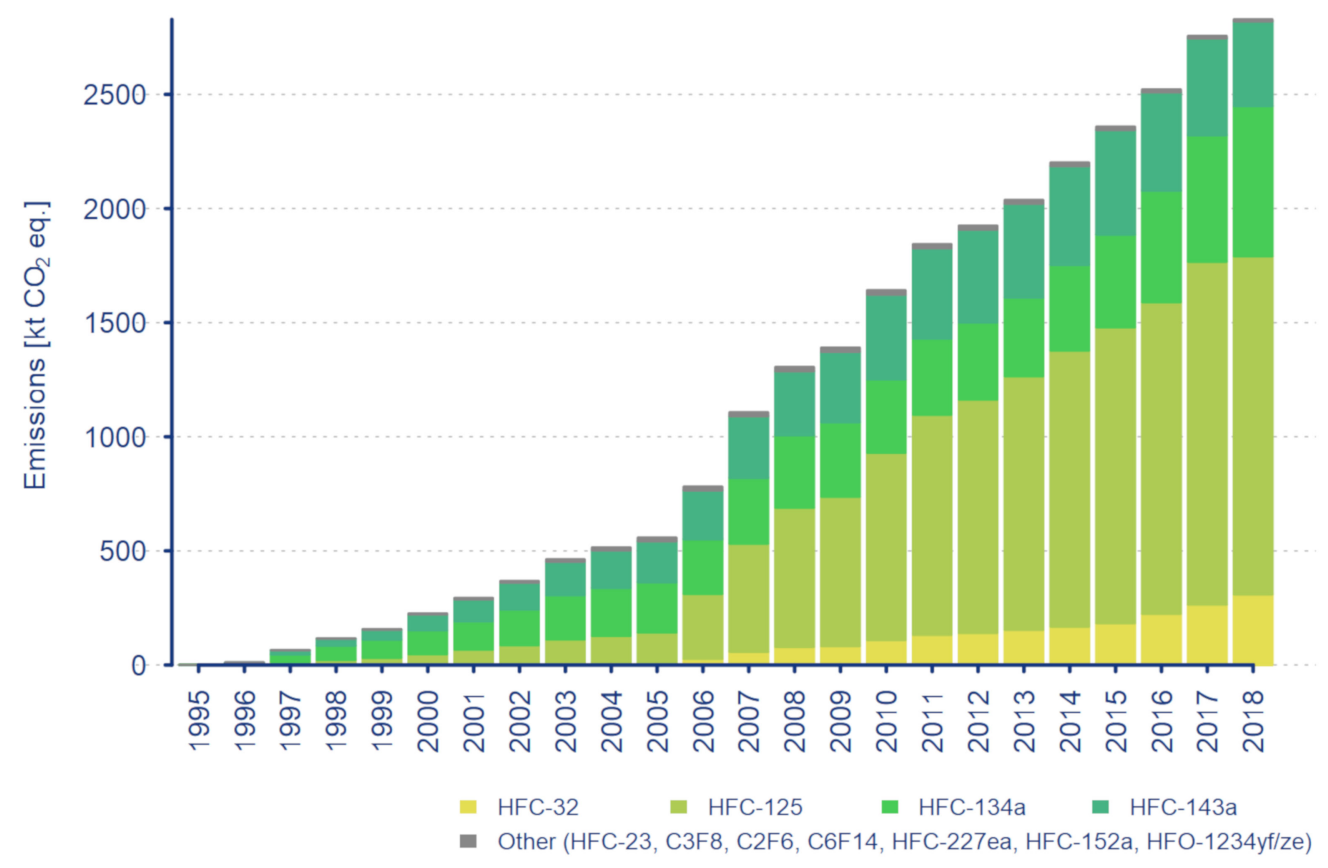

Figure 4. The trend in emissions from refrigeration and stationary air conditioning in the Czech Republic. 


\section{Concluding Remarks}

Because F-gases have been used as substitutes for ozone-depleting substances, their consumption has been increasing strongly since 1995. The main sector where F-gases are employed is in refrigeration and air-conditioning systems. Because of the large global warming potential of F-gases, the EU has adopted legislative measures to prevent a further increase in their emissions. Alternative solutions to F-gases are already on the market. On the basis of the collected data, it can be seen that consumption of F-gases stopped increasing even before main part of EU legislative measures came into force. Therefore, in the coming years, especially from 2020, we expect a gradual decrease in the consumption of F-gases in refrigeration and stationary air-conditioning systems. No decrease is expected in mobile air-conditioning systems.

A more important factor than consumption itself is the composition of the consumed F-gases, because there can be big differences in the impact on global warming between individual gases. There, we can see great progress. In recent years, manufacturers started using new gases, especially HFO-1234yf with very low global warming potential, which is the main refrigerant in mobile air conditioning at the present time and we can expect that it will also be used more widely in other sectors in the coming years. Currently, HFO-1234yf is mainly used in transport refrigeration (except mobile air conditioning), whereas HFO-1234ze is mainly used in commercial refrigeration.

Since HFO-1234yf and HFO-1234ze will certainly become an integral part of the refrigeration industry, these two gases were implemented into the PHOENIX model, the country-specific estimation model for F-gas emissions. The base year of their use in refrigeration and stationary air conditioning is 2018. Newly applied F-gases changes the results of the F-gas emissions in the Czech Republic and affects in this way also the total emission from green-house gases. However, since time lag between consumption and emissions is taken in account, changes in emission trend will appear with delay.

The new F-gases have lower global warming potential than those used earlier, which is a great benefit. But they are also subject to some scepticism since their characteristics have not been examined in sufficient detail yet. One already known problem is their flammability, which ranks them in category A2L. Category A2Lcompounds are slightly flammable and exhibit low toxicity. Their low toxicity has been demonstrated by their high effective doses in toxicological experiments conducted on mammals (mice, dogs, etc.). This toxicological information was also employed for adjustment of WEEL values, which are higher than $400 \mathrm{ml} . \mathrm{m}^{-3}$ for the newly employed F-gases [26]. Despite their low toxic potential, they should not be taken lightly. Their harmful effect could be hidden in the future and better information will be gained from future epidemiologic studies.

Author Contributions: M.M.: Data curation, Methodology, Writing-original draft; E.K.: Methodology, Supervision, Writing-review \& editing, Z.R.: Methodology, Writing-original draft. All authors have read and agree to the published version of the manuscript.

Funding: This research received no external funding.

Conflicts of Interest: The authors declare no conflict of interest.

\section{References}

1. EU Legislation to Control F-Gases Climate Action. Available online: https://ec.europa.eu/clima/policies/fgas/legislation_en\#tab-0-0 (accessed on 14 January 2020).

2. Fluorinated Greenhouse Gas. Available online: https://dccae.gov.ie/en-ie/environment/topics/air-quality/ fluorinated-greenhouse-gas/Pages/default.aspx (accessed on 14 January 2020).

3. Fluorované Skleníkové Plyny-Ministerstvo Životního Prostředí. Available online: https://www.mzp.cz/cz/ fluorovane_sklenikove_plyny (accessed on 11 February 2020).

4. Myhre, G.; Shindell, D. (Eds.) Anthropogenic and Natural Radiative Forcing. In Climate Change 2013: The Physical Science Basis. Contribution of Working Group I to the Fifth Assessment Report of the Intergovernmental Panel on Climate Change; Cambridge University Press: Cambridge, UK; New York, NY, USA, 2013; pp. 659-740. 
5. US EPA. Understanding Global Warming Potentials Greenhouse Gas (GHG) Emissions. Available online: https://www.epa.gov/ghgemissions/understanding-global-warming-potentials (accessed on 18 February 2020).

6. Directive 2006/40/EC of the European Parliament and of the Council of 17 May 2006 Relating to Emissions from Air Conditioning Systems in Motor Vehicles and Amending Council Directive 70/156/EEC (Text with EEA Relevance). Official Journal of the European Union: Brussels, Belgium, 2006; pp. 12-18.

7. Quota Allocation, the HFC Registry and Data Reporting. Available online: https://ec.europa.eu/clima/ policies/f-gas/reporting_en (accessed on 18 February 2020).

8. Regulation (EU) No 517/2014 of the European Parliament and of the Council of 16 April 2014 on Fluorinated Greenhouse Gases and Repealing Regulation (EC) No 842/2006 Text with EEA Relevance. Official Journal of the European Union: Brussels, Belgium, 2014; pp. 195-230.

9. Řeháček, V. Antropogenní emise fluoridu sírového, fluoridu dusitého, částečně fluorovaných uhlovodíků a zcelafluorovaných uhlovodíků v roce 2015 v České republice, Praha, 2016.

10. CHMI. National Inventory Report; Czech Hydrometeorological Institute: Praha, Czech Republic, 2020.

11. Cavallini, A.; Zilio, C. Carbon dioxide as a natural refrigerant. Int. J. Low Carbon Technol. 2007, 2, $225-249$. [CrossRef]

12. Low GWP Synthetic Refrigerants. Available online: https://www.danfoss.com/en/about-danfoss/ourbusinesses/cooling/refrigerants-and-energy-efficiency/refrigerants-for-lowering-the-gwp/low-gwpsynthetic-refrigerants/ (accessed on 11 February 2020).

13. Occupational Alliance for Risk Science-Workplace Environmental Exposure Levels (WEEL). Available online: https://www.tera.org/OARS/OARS\%20WEELS\%20Jan\%202014.pdf (accessed on 9 March 2020).

14. Solstice ${ }^{\mathrm{TM}}$ ze (HFO-1234ze) Refrigerant. Available online: https://www.climalife.co.uk/docs/Solstice\% 201234ze\%20brochure.pdf (accessed on 9 March 2020).

15. Gil, B.; Kasperski, J. Efficiency Evaluation of the Ejector Cooling Cycle using a New Generation of HFO/HCFO Refrigerant as a R134a Replacement. Energies 2018, 11, 2136. [CrossRef]

16. Fedele, L.; Di Nicola, G.; Brown, J.S. Measurements and Correlations of cis-1,3,3,3-Tetrafluoroprop-1-ene (R1234ze(Z)) Saturation Pressure. Int. J. Thermophys. 2014, 35, 1-12. [CrossRef]

17. Daviran, S. A comparative study on the performance of HFO-1234yf and HFC-134aas an alternative in automotive air conditioning systems. Appl. Therm. Eng. 2017, 110, 1091-1100. [CrossRef]

18. Brož, J. Nové Chladivo HFO 1234yf-Budoucnost Již Začala. Available online: http://portal.sda-cia.cz/clanky/ download/2012-07-Chladivo-HFO.pdf (accessed on 9 March 2020).

19. Minor, B.; Spatz, M. HFO-1234yf Low GWP Refrigerant Update. In Proceedings of the International Refrigeration and Air Conditioning Conference, Purdue, IN, USA, 14-17 July 2008; p. 937.

20. Honeywell Solstice®ze Refrigerant (HFO-1234ze): The Environmental Alternative to Traditional Refrigerants. Available online: https:/www.honeywell-refrigerants.com/india/?document=solstice-zehfo-1234ze-brochure-2012\&download=1.\%20FPR-003/2015-01 (accessed on 11 February 2020).

21. Khandelwal, P. E/Z System of Nomenclature of Geometrical Isomers. Available online: https://biyanicolleges. org/ez-system-of-nomenclature-of-geometrical-isomers/ (accessed on 11 February 2020).

22. Rusch, G. The acute, genetic, developmental and inhalation toxicology of trans-1,3,3,3-tetrafluoropropene (HFO-1234ze). Drug Chem. Toxicol. 2012, 36, 170-180. [CrossRef] [PubMed]

23. Westfalen. Available online: http://www.westfalen.cz/fileadmin/user_uploads/Westfalen_Tschechien/ Prospekte/IP5_CZ_verze_pro_Web.pdf (accessed on 11 March 2020).

24. IPCC. IPCC Guidelines for National Greenhouse Gas Inventories; Institute for Global Environmental Strategies (IGES) for the IPCC: Kanagawa, Japan, 2006; ISBN 4-88788-032-4.

25. Ondrušová, B.; Krtková, E. The Phoenix calculation model for emission estimates of F-gases used in refrigeration and air conditioning. Meteorol. Zprávy 2018, 1, 24-29.

26. SAFTENG. Available online: https://www.safteng.net/index.php/free-section/safety-info-posts/chemicalprocess-safety-psmrmp/3946-refrigerant-hfo-1234yf-and-flame-retardant-clothing-part-5 (accessed on 11 March 2020).

(C) 2020 by the authors. Licensee MDPI, Basel, Switzerland. This article is an open access article distributed under the terms and conditions of the Creative Commons Attribution (CC BY) license (http://creativecommons.org/licenses/by/4.0/). 